
OF WINE AND CHEESE

\author{
Ricardo Sellers-Rubio \\ Francisco J. Más-Ruiz \\ Universidad de Alicante
}

Puede citar este artículo como:

Sellers-Rubio, R. y Mas-Ruiz, F. (2015) "Economic efficiency of members of protected designations of origin: sharing reputation indicators in the experience goods of wine and cheese”. Review of Managerial Science. Vol. 9, nº 1, pp. 175-196.

DOI 10.1007/s11846-014-0124-X 


\title{
ECONOMIC EFFICIENCY OF MEMBERS OF PROTECTED DESIGNATIONS OF ORIGIN: SHARING REPUTATION INDICATORS IN THE EXPERIENCE GOODS OF WINE AND CHEESE
}

\begin{abstract}
The aim of this paper is to analyse the economic efficiency of members of Protected Designations of Origin (PDO). For the first time we analyse the value of PDO labels from the point of view of economic efficiency. The central hypothesis is that a PDO has a positive impact on the economic efficiency of its member companies and that this is because a PDO label is a collective reputation indicator that foments efficient investment in quality in terms of member returns. The methodology applied to test this hypothesis is based on Data Envelopment Analysis (DEA) to estimate economic efficiency, and econometric models to explain company efficiency through both the PDO label, as an indicator of collective reputation, and the characteristics of the company. The results obtained in the experience goods of wine and cheese in Spain show that PDO labels have a positive impact on economic efficiency. Additionally, the age and size of the company have a positive effect while the wage level of the company has a different influence on efficiency depending on the sector considered. Overall, the results reveal the importance of PDOs in industries in which the signal of reputation is not only reliant on the individual brands.
\end{abstract}

KEY WORDS: PDO, collective reputation, efficiency, experience goods, wine, cheese sector

JEL CODE: M30 


\section{Introduction.}

Collective brands have proliferated in recent years, and the products marketed under these brands now represent an important percentage of consumer purchases (Winfree and McCluskey, 2005). This tendency in consumer preferences has led the European Union to introduce the following public labels (Fernández-Barcala and González-Díaz, 2006; Loureiro and McCluskey, 2000): Protected Designation of Origin (PDO), Protected Geographical Indicator (PGI) and Guaranteed Traditional Speciality (GTS). A PDO covers the term used to describe foodstuffs which are produced, processed and prepared in a given geographical area using recognized know-how (e.g., Mozzarella di Bufala). A PGI indicates a link with the geographical area in at least one of the stages of production, processing or preparation (e.g., Turrón de Alicante). The link with the area is therefore stronger for PDOs and the level of protection is also stronger for PDOs. Two examples of products that can be categorized as PDOs are wine and cheese, and they are the object of our study. Finally, Guaranteed Traditional Specialities are agricultural products and foodstuffs that comply with certain specifications concerning their composition or method of production.

A determinant of the success of products under the umbrella of these labels is collective reputation: if the collective reputation of the product is high, the collective label will be a powerful indicator of quality (Tirole, 1996). In this way, collective labels created by public or government institutions are designed to ratify the product quality of the individual member companies, which can sell their products with a legal guarantee and the prestige of the superior quality of the specified geographical region and/or production method.

The wide use of the collective label strategy has provoked interest in the academic world but the extant studies are only based on estimating collective brand equity through the price premium consumers are ready to pay (e.g. Fernández Barcala and González Díaz, 2006) and on the impact of collective reputation indicators on product price (e.g. Landon and Smith, 1997, 1998; Loureiro and McCluskey, 2000; Schamel, 2000). This has allowed the characterisation of collective labels through two main features (Fishman, Finkelshtain, Simhon and Yacouel, 2008): i) their labels are perceived as signs of superior quality by consumers, who are prepared to pay a price premium for them; and ii) the 
member producers of collective labels only share a brand name, and are generally autonomous companies that take individual decisions and make their own profits.

In any case, we can ask ourselves what the efficiency of a member company of a PDO label would be and whether there are conditions that affect this efficiency. The efficiency of a company refers to a relative judgement around the relationship between the resources used -inputs- and the results obtained -outputs- in the development of its activities; bearing in mind that between the two elements is the underlying idea of opportunity costs. A company will be efficient if, given a certain availability of inputs, it is able to produce the maximum amount of output possible; or, alternatively, if it can reach a certain level of output using the lowest quantity of inputs possible. The efficiency of a company has a relative character, as it includes the performance of the other companies that make up the sample. The interest in studying these aspects rests on their important implications on managers' decisions in terms of the effectiveness of public PDO labels in creating value-added for producers.

Thus, the objective of this study is to examine the capacity of a PDO label to generate greater performance from a company efficiency perspective while controlling the role of the different characteristics of the member companies. The central hypothesis is that a PDO has a positive impact on the economic efficiency of its member companies and that this is because a PDO label is a collective reputation indicator in experience goods (i.e., the quality of a product is imperfectly observable prior to purchase) that foments efficient investment in quality in terms of member returns. The methodology is based on the non-parametric efficiency estimation technique of Data Envelopment Analysis (DEA) and on the application of different regression models that explain company efficiency through both the PDO label, as an indicator of collective reputation, and the characteristics of the company. The empirical analysis is made on PDO labels in the experience goods of wine and cheese in Spain; two interesting examples for our purposes given the proliferation in the wine and cheese markets of PDO labels. Concretely, PDOs are used in Spain as a recognition of superior quality, resulting from individual differential characteristics due to the geographical environment where the raw materials are produced and the product is made and the influence of the human factor (MMAMRM, 2009). These PDOs are used by a plurality of companies under the control and 
authorisation of the titleholder (the Regulatory Council of each PDO), which certifies that the products comply with certain common requisites, especially those concerned with quality, geographical origin, technical conditions or method of production.

Having established the objective of the study, the rest of the paper is organised as follows. In the second section we develop and argue the hypothesis. The third describes the methodology and sample used. In the fourth section, we present the results and the final section summarises the conclusions made from the study.

\section{Literature review and development of the hypothesis.}

Researchers have given little empirical attention to the relationship between collective brands and the efficiency of their member companies. Despite this, the traditional theoretical position in Industrial Economy holds that collective labels can increase the efficiency of their members by providing scale economies in production and promotion (Fishman et al., 2008), meaning that companies in collective brands would be more efficient than those that do not use collective brands. With regard to scale economies in production (see Tirole, 1988), the bringing together of activities, derived from the same product or from different products, is related to reduced production costs. Thus, participation in a collective brand facilitates specialisation and brings significant savings. Moreover, coordinated activities are motivated by complementariness of demand. One can imagine a diversity of companies specialising in wine making, but the coordination required by membership of a PDO creates synergy. In this way, collective brands can deliver scale economies in production for their member companies. In terms of scale economies in promotion, the grouping together of activities can not only be associated with production in the strict sense of the word, but also with the services that accompany it (Tirole, 1988), such as promotion. Such groupings avoid the duplication of the fixed costs of promotion or they at least reduce them. In fact, one of the objectives sought by the use of collective brands is to reduce the marketing investment needed to launch new products.

Although the effects derived from scale economies in production and promotion could explain the greater efficiency of companies in collective brands, the logic of our proposal is based, alternatively, 
on the idea that collective labels are economically efficient in signalling quality when some characteristics of the product cannot be observed by consumers before or after its purchase.

\subsection{Economic efficiency in signalling quality.}

Our proposal begins with the Signalling Theory of the Information Economics (see Erdem and Swait, 1998; Kreps and Wilson, 1982), which refers to the role of brand reputation as a quality indicator that reduces the perception of risk in conditions of asymmetric information on quality in the market. Basically, this theory assumes the existence of imperfect and asymmetric information in markets. When these information asymmetries refer to quality, high and low quality products can co-exist in the market (Akerlof, 1970), which means that consumers have to make ex-ante evaluations of the quality of their purchases; making the choice both problematic and costly (Nayyar, 1990) as there will be doubts around the quality of a product and the consumer will not know a priori which product to buy. Assuming rational consumer behaviour, we can expect consumers to try to make good purchases and reduce risk; meaning that the purchase decision process will be guided by any intrinsic and/or extrinsic signals of quality. One of the most analysed signals for reducing these asymmetries in consumer markets is brand reputation (Kreps and Wilson, 1982; Erdem and Swait, 1998). In fact, brand value is defined by the utility it gives the consumer as an information signal (e.g. Erdem et al., 1999), which means that the main determinant of brand value is consumer belief in the brand, which can help improve perception of quality and reduce the search costs and risk associated with purchase.

In this respect, the researchers of Industrial Economy distinguish two reputation models (Landon and Smith, 1997, 1998): individual company reputation and collective reputation. The role of individual company reputation has been developed in the theoretical models of Klein and Leffler (1981), Kreps et al. (1982), Shapiro (1983), Allen (1984), Rogerson (1987) and Jin and Leslie (2009), who explain the reputation of an individual company through its past output quality. Thus, with experience goods, the quality of a product is imperfectly observable prior to purchase and can only be determined through its use. If these experience goods are not frequently bought, the information on the current quality of the product is not available to consumers or is costly to acquire. This means that consumer demand will depend, at least in part, on consumer predictions around the quality of the product. In this sense, these 
models consider that the reputation of an individual company is only a function of its past quality and proposes that the price of an individual company's product is explained by its reputation based on the past quality of its output ${ }^{1}$.

For its part, the role of collective reputation, understood as an aggregate of individual reputations, is developed in the theoretical model of Tirole (1996), which uses group information to approximate the quality of the product of the individual company. In fact, in industries with a large number of producers, the specific information on the current or past quality of a given company is not easily available and it will only be possible (or it would be cheaper) to obtain information on the quality of a group of companies with which the company in question can be identified. This group information can be used as an indicator of the product quality of an individual company in the group.

In summary, among the mechanisms of reputation, the collective label stands out as the individual member companies share a collective reputation and the consumers of a given individual company can learn something about the quality of all the member companies. In any case, our proposal considers that collective reputation foments efficient investment in quality in terms of returns ${ }^{2}$ of members that produce experience products (i.e.: where quality is difficult to observe before purchasing). It is argued through the following extension of the ideas of Shapiro (1983): if consumers rely on the quality reputation of a group of companies, a company that chooses to join a collective label with a certain level of quality initially has to invest in reputation through the production of quality products, and continue the quality strategy over time as it will obtain high profits from its investment in quality derived from the large number of consumers that are adequately informed about the past quality of the group (Fishman et al., 2008). In fact, a collective label covers a larger market segment than any of its member companies, and given that the information on past quality is imperfectly disseminated, for

\footnotetext{
${ }^{1}$ An earlier theoretical specification, collected in the incomplete information model (see Rosen, 1974), assumes that consumers have access to low-cost or free information on the current quality of a product.

${ }^{2}$ Another theoretical position, which has not been empirically analysed, holds that the members of a public collective label, such as PDO, can be more inefficient than members of a private collective label due to their higher variable production costs (Bouamra-Mechemache and Chaaban, 2010). Basically, public labels are governed by a different set of legislation and limitations to guarantee a certain quality; for example, regulation induces technology constraints linked to a specific processing requirement and production area. In contrast, companies in a private collective labelling scheme can improve their efficiency as they have less stringent technical and capacity requirements, which entail lower variable production costs.
} 
example by word of mouth, the consumers of any given member company have a greater probability of having previously interacted with past consumers of the collective label than with those of a company outside the collective. Consequently, a collective label can promote more efficient investment in quality in its member companies in terms of returns on this investment.

Taking the above argumentation, we can expect PDO labels to increase the economic efficiency of their members because the PDO label provides a collective reputation indicator which foments efficient investment in quality in terms of the improvement of its members' returns ${ }^{34}$. Consequently, we propose the following hypothesis:

H1. Companies that use PDO labels are more efficient from an economic point of view than companies that do not use PDO labels.

\section{Methodology and sample.}

\subsection{Methodology.}

The methodology is based on the estimation of the economic efficiency of a company, as well as on the different non-parametric tests to analyse the relationship between the PDO label, as a collective reputation indicator, and company economic efficiency. With regard to the first aspect, various models have been proposed to estimate efficiency. In this study economic efficiency is estimated using the non-parametric methodology of Data Envelopment Analysis (DEA) (Charnes et al., 1978, 1981), which is based on linear programming techniques, in which it is not necessary to include specific

\footnotetext{
${ }^{3}$ Our hypothesis follows the theoretical assumption that reputation plays an important role in assuring product quality in markets where consumers can only imperfectly judge the product quality after consumption. Thus, if reputation effects are absent in these markets, producers have incentives to reduce quality to make short terms gains; that is, a declining trend in reputation gives producers a license to free-ride on the collective reputation. However, to avoid this reduction in quality, products with a good reputation are sold with a price premium (Quagrainie, McCluskey and Loureiro, 2003); in fact, Shapiro (1983) showed theoretically that price premiums are needed for producers to invest in quality and reputation.

${ }^{4}$ Alternatively, the theoretical position of Fishman et al. (2008) holds that if the consumers' perception of quality of a collective brand is determined by their experience of the quality of different members of the brand and if the supply of high quality requires high investment, members may have the incentive to adopt a free-riding attitude to the investments of the other members of the collective brand. In fact, if the costs are sustained by all the producers but incomes are shared amongst the members according to the quantity produced, with no regular controls or minimum quality standards, some companies can be led away from the path of virtue and reduce quality in order to minimise costs and maximise profits (Castriota and Delmastro, 2008). In this way, "free-riding" can be affected by the number of companies and the production volume of the collective brand: when the number of member companies is not large, it is possible to perfectly track the investments of the members and identify members that do not invest, thus impeding "free riding". And as the production volume increases in the collective brand so does the collective reputation effect (as the number of units whose quality is observed by consumers increases) and the incentives to invest, eliminating the incentive to free ride.
} 
functional forms for the production function (relationship between inputs and outputs) to establish the efficient frontier.

In general, DEA is an extension of the traditional ratios analysis insofar as each decision making unit (DMU) evaluated is considered efficient if no other DMU is able to produce higher outputs from the same inputs or, alternatively, produce the same output using lower input levels. In the literature on productivity and efficiency analysis the term DMU is used to describe a productive entity such as a company, a retail outlet, a bank branch, or a business unit. The underlying assumption is that these decision making units employ the same type of inputs to obtain the same type of outputs. In our case, we employ the term DMU referring to a company (winery or cheese factory). With the DEA models we can distinguish units (companies) that operate efficiently from those that do not, with the efficient units defining the efficient frontier.

More concretely, we apply an output orientated model (it considers that a company will be efficient if, given a certain availability of inputs, it is able to produce the maximum amount of output possible), bearing in mind that the input and output orientated models estimate exactly the same frontiers and, therefore, identify the same companies as efficient. If we consider the existence of $n$ homogenous decision making units $\left(\mathrm{DMU}_{\mathrm{j}} ; \mathrm{j}=1, \ldots ., \mathrm{n}\right)$, whose efficiency we intend to evaluate, they can be characterised by a vector of $m$ inputs $X_{j}=\left(x_{1 j}, X_{2 j}, \ldots, X_{m j}\right)$ and a vector of $s$ outputs $Y_{j}=$ $\left(\mathrm{y}_{1 \mathrm{j}}, \mathrm{y}_{2 \mathrm{j}}, \ldots, \mathrm{y}_{\mathrm{sj}}\right)$. For each DMU we solve the following linear programming problem of the BCC model (Banker et al, 1984):

$$
\begin{array}{lc}
\max & \theta+\varepsilon \sum_{r=1}^{s} s_{r}^{+}+\varepsilon \sum_{i=1}^{m} s_{i}^{-} \\
\text {s.a. } & \sum_{j=1}^{n} x_{i j} \lambda_{j}+s_{i}^{-}=x_{i 0} \\
& \sum_{j=1}^{n} y_{r j} \lambda_{j}-s_{r}^{+}=\theta y_{r 0} \\
& \sum_{j=1}^{n} \lambda_{j}=1 \\
& \lambda_{j}, s_{r}^{+}, s_{i}^{-} \geq 0
\end{array}
$$

Where $\theta$ is the measurement of efficiency obtained for the analysed unit and $\varepsilon$ is a value that is positive and close to zero. The parameters $\lambda_{j}$ represent the relative weights of the inputs and outputs for all the restrictions that keep the efficiency of each unit from being higher than one. Hence, a DMU 
(a company) would be considered efficient if $\theta^{*}=1$ and all the slack variables $s_{r}^{+}$and $s_{i}^{-}$are zero, while for the non-efficient units, the slack variables indicate the excess input or lack of output of each DMU. In fact, the slack variables $s_{r}^{+}$and $s_{i}^{-}$, indicate that if $s_{r}^{+}$has a positive value it is possible to increase the output of the evaluated unit $\mathrm{y}_{0}$ by a quantity equal to the value of the same variable $\mathrm{y}_{0}+s_{r}^{+}$ without changing the value of any $\lambda_{\mathrm{j}}$ and without violating any restriction. Similarly, if $s_{i}^{-}$has a positive value, the input level can be reduced from $\mathrm{x}_{0}$ to $\mathrm{x}_{0}-S_{i}^{-}$. The resolution of the above linear programming problem for each unit allows us to identify the efficient units $\left(\theta^{*}=1\right.$ and slack variables of zero) that make up the reference frontier of the non-efficient units $\left(0<\theta^{*}<1\right)$. The degree of efficiency of the inefficient units is given by the parameter $\theta^{*}$, so that the larger the estimation, the larger the degree of efficiency of the evaluated unit.

The above model implicitly assumes variable returns to scale. Returns to scale is a long run concept which reflects the degree to which a proportional increase in all inputs increases output. Constant returns to scale (CRS) occurs when a proportional increase in all inputs results in the same proportional increase in output. Variable returns to scale (VRS) occurs when a proportional increase in all inputs results in a more than proportional increase in output (increasing VRS) or in a less than proportional increase in output (decreasing VRS). The CRS assumption is only appropriate when all companies are operating at an optimal scale. However, when this is not the case, efficiency measurements can be confounded by scale efficiencies. The use of a VRS specification permits the calculation of efficiency devoid of these scale efficiency effects. Thus, to estimate scale efficiency we have to solve the above linear problem with the elimination of restriction of convexity, which gives us the CCR model (Charnes et al., 1978), which assumes constant returns to scale (CRS). The efficiency measurements obtained with this model $\left(\theta^{*} \mathrm{CRS}\right)$ are always lower than those obtained with the BCC model (Banker et al, 1984) $\left(\theta^{*}{ }_{\text {VRS }}\right)$, which assumes variable returns to scale (VRS), so that scale economies (SE) are defined as $\theta^{*}{ }_{\mathrm{CRS}} / \theta^{*}{ }_{\text {VRS. }}$. If $\mathrm{SE}_{\mathrm{i}}=1$, the DMU analysed operates with scale efficiency, whereas if $\mathrm{SE}_{\mathrm{i}}<1$, it indicates the presence of scale inefficiencies. 
Second, to test whether PDO labels influence efficiency (Hypothesis 1) we use a series of nonparametric tests with the estimations of the efficiency of the different companies. Concretely, we apply the test of Mann-Whitney to the null hypothesis that the sample means of the different groups of companies are generated by the same density function, as opposed to the alternative hypothesis that the efficiency of a group is stochastically better than that of another. At this point, it is useful to remember that the estimated efficiency values are not independently distributed and that it is not possible to apply the central limit theorem, which impedes the application of a variance analysis as it does not meet the assumption of normality in the distributions of the indices of efficiency. Finally, to control the influence of some of the characteristics of the company on the relationship between the PDO label, as a collective reputation indicator, and the efficiency of the company, we also use a regression analysis. Concretely, we make a second stage analysis in which the efficiency estimations of each company are explained as a function of a dummy variable (that takes the value 1 if the company belongs to a PDO and 0 otherwise), the age of the company, the average wages paid by the company and the company size. Given that the estimated efficiency values are restricted to between 0 and 1, the usual procedure for this type of analysis is to employ a Tobit regression model estimated by maximum likelihood (e.g. Bravo-Ureta et al., 2007). Hoff (2007) indicates that this type of model is sufficient to analyse the effect that certain independent variables have on efficiency levels estimated through DEA. We have conducted two different regressions because the efficiency estimates for the wineries and the cheese factories are not comparable since they are specific for the sample considered.

\subsection{Sample, data and variables.}

The empirical analysis is performed on two samples of companies operating in the Spanish wine and cheese sectors, respectively. For the samples selection we use the populations of companies registered in paragraphs 1042 and 1053 of CNAE-2009, which are the equivalent of codes 2084 ("Wines, brandy and brandy spirits") and 2022 ("Natural, Processed, and Imitation Cheese”) of the US SIC classification, and which are found in the SABI database (the Iberian version of the Bureau Van Dijk database). The initial sample comprises 2,563 companies in the wine sector and 456 in the cheese sector. To guarantee the homogeneity of the companies analysed, we exclude wineries that principally 
produce brandy and other distilled high alcohol products. When this database does not provide information on certain relevant variables (especially with regard to employee numbers at wineries), we use information from the FEV (Spanish Wine Federation). Finally, 46 wineries were contacted by email and/or telephone to complete the information on some of the variables needed to estimate efficiency. The companies in the 80 Spanish wine PDOs and in the 27 Spanish cheese PDOs are listed on the PDO websites. The final sample used for the empirical study is made up of 1,257 wineries, of which 437 are not members of any PDO, and of the 820 that are members of the 58 PDOs represented in the sample, 110 wineries are members of more than one PDO. The final sample of cheese factories is made up of 378 companies, of which 267 are not members of any PDO, and 111 are members of the 22 PDOs represented in the sample.

With regard to the variables used to estimate economic efficiency, we consider different representative inputs and outputs of the economic activity of the companies considered. As inputs, we use the following three productive factors: i) the number of employees, which represents the labour factor (Bucklin, 1978; Ingene, 1982; Pilling et al., 1995; Yoo et al., 1997; Thomas et al., 1998); ii) the funds of the company (capital plus reserves); and iii) the level of debt (long and short term). The last two variables are used as an alternative to a single capital variable as access to financing and the costs derived from it are a fundamental factor of international competition in the wine industry (Viviani, 2008).

In terms of outputs, firstly we use sales volumes (Bucklin, 1978; Ingene, 1982; Lusch and Serpkenci, 1990; Ratchford and Stoops, 1988; Donthu and Yoo, 1998; Thomas et al., 1998; Zhu, 2000). The justification of this choice is that companies work with a wide range of products (e.g., red, white, or rosé wines with different qualities and prices), which makes it impossible to obtain disaggregated information on the outputs produced. As a second output we use the profit volumes of the company (Bucklin, 1978; Doutt, 1984; Thomas et al., 1998; Zhu, 2000) for the following reasons: i) companies can obtain atypical returns distinct from their principal activity which are not included in their sales volume figures; ii) along with sales volumes, company managers have to pay special attention to results, as they guarantee both the visibility of the company and the possibility of making future 
investments; and iii) considering profit levels allows us to include the influence of costs not considered as inputs. The consideration of these two outputs in monetary terms allows us to estimate an eminently economic concept of efficiency. We do not consider outputs in physical terms (for example, hectolitres of wine produced or tonnes of cheese produced) because this would entail estimating a technical concept of efficiency outwith the scope of this study.

Finally, in order to explain the estimated efficiency of the companies we consider the following variables. First, a collective reputation indicator, measured through a dummy variable that takes the value 1 if the winery or cheese factory belongs to a PDO and 0 otherwise (Landon and Smith, 1997, 1998). Second, as control variables we use three company characteristics: i) Age of the company, measured in years since its creation. More age leads to better market knowledge and better individual company reputation. Thus, as a company establishes itself within a community, its awareness and reputation spread with positive word of mouth (Thomas et al., 1998). In this sense, greater age allows a company to have more know-how, which can lead to more capacity to develop its activities more efficiently. So, in principle, we can expect that the older companies will be more efficient than the newer companies. ii) Average wage paid (Gómez-Mejía and Balkin, 1992), measured as the quotient between the total amount destined for salaries and the number of employees at the company. This variable, related to the management of human resources, can have an impact on the efficiency of a company. The agency theory (Tosi and Gómez-Mejía, 1994), in the field of contractual or agency relationships between company and employee (Jensen and Meckling, 1976), states that an adequate remuneration system aligns the interests of the principal (company) and the agent (employee) (Jensen and Meckling, 1976; Schulze et al., 2001). The design of the optimum remuneration system entails the use of a great number of dimensions (Gómez-Mejía and Balkin, 1992; Sánchez and Aragón, 2003), especially the level of remuneration, and determines the total amount paid to each employee with regard to the market average (Balkin and Gómez-Mejía, 1990; Sánchez and Aragón, 2003). The existing empirical findings around the relationship between average remuneration level and company efficiency are not conclusive, which could be because of the existence of contextual or situational factors (Sánchez and Aragón, 2002). And iii) Size of the company, measured as the assets volume. 
Company size can affect economic efficiency because it can explain individual reputation as bigger companies have more financial resources to invest in quality and promotion (Castriota and Delmastro, 2008). Table 1 shows the descriptive statistics of the variables used.

TABLE 1. DESCRIPTIVE STATISTICS OF THE VARIABLES USED

\begin{tabular}{|c|c|c|c|c|c|c|c|c|c|}
\hline & Variable & $\begin{array}{c}\text { Sales } \\
(1000 \mathrm{~s} \\
\text { of euros) }\end{array}$ & $\begin{array}{c}\text { Profits } \\
\text { (1000s } \\
\text { of euros) }\end{array}$ & $\begin{array}{c}\text { Employees } \\
\text { (number) }\end{array}$ & $\begin{array}{c}\text { Funds } \\
\text { (1000s } \\
\text { of euros) }\end{array}$ & $\begin{array}{c}\text { Debt } \\
(1000 \mathrm{~s} \\
\text { of euros) }\end{array}$ & $\begin{array}{l}\text { Age of } \\
\text { the } \\
\text { company } \\
\text { (years) }\end{array}$ & $\begin{array}{c}\text { Wages } \\
\text { paid } \\
\text { (1000s } \\
\text { of euros) }\end{array}$ & $\begin{array}{c}\text { Assets } \\
\text { (1000s } \\
\text { of euros) }\end{array}$ \\
\hline \multirow[t]{4}{*}{ Wine } & Mean & 4117.72 & 208.91 & 16.61 & 3984.12 & 4131.23 & 16.34 & 22.02 & 8542.51 \\
\hline & S.D. & 20447.16 & 1747.34 & 60.03 & 18146.61 & 14799.12 & 13.82 & 12.25 & 31330.66 \\
\hline & Max. & 409504 & 30747 & 1363 & 338537 & 301782 & 108 & 53.47 & 506260 \\
\hline & Min. & 1 & -20200 & 1 & 1 & 0 & 1 & 5 & 7 \\
\hline \multirow[t]{4}{*}{ Cheese } & Mean & 5786.31 & 432.75 & 18.03 & 1935.15 & 2327.73 & 14.54 & 20.81 & 4262.88 \\
\hline & S.D. & 27125.59 & 3330.79 & 54.55 & 9308.04 & 7918.09 & 10.72 & 7.95 & 16473.59 \\
\hline & Max. & 371546 & 50765 & 658 & 97313 & 101466 & 94 & 60 & 192052.23 \\
\hline & Min. & 2 & -1852 & 1 & -1511 & 3 & 0 & 6 & 3.18 \\
\hline
\end{tabular}

\section{Results.}

In this section we first estimate the economic efficiency of the companies, using the DEA methodology. As can be seen in Table 2, the average economic efficiency using the DEA models that assume constant returns to scale (CRS) and variable returns to scale (VRS) is 0.431 and 0.477 , respectively, which reflects a high degree of inefficiency among Spanish wineries. This result implies that, on average, the wineries considered could have attained the same levels of output using 55\% fewer inputs. The average scale efficiency of the sample analysed is 0.925 , which means that the largest part of the deviation from the efficient frontier is due to poor use of inputs and, to a lesser extent, because the wineries are not operating at the optimum size. In the case of cheese factories, the average economic efficiency using the CRS and VRS models are 0.372 and 0.422 , respectively, which also reflects a high degree of inefficiency among the cheese factories. This result implies that, on average, the cheese factories considered could have attained the same levels of output using $60 \%$ fewer inputs. The average scale efficiency of the sample analysed is 0.894 .

With the model that assumes CRS there are 64 wineries (23 cheese factories) considered economically efficient. With the model assuming VRS there are 183 wineries (41 cheese factories) considered economically efficient. Finally, the results show that there are 295 wineries (52 cheese factories) with optimum scale efficiency. 
TABLE 2. ESTIMATIONS OF EFFICIENCY

\begin{tabular}{|c|c|c|c|c|c|c|}
\hline & \multicolumn{3}{|c|}{ Wine } & \multicolumn{3}{c|}{ Cheese } \\
\cline { 2 - 7 } & CRS Eff. & VRS Eff. & SE Eff. & CRS Eff. & VRS Eff. & SE Eff. \\
\hline Mean & 0.431 & 0.477 & 0.925 & 0.372 & 0.422 & 0.894 \\
S.D. & 0.264 & 0.284 & 0.150 & 0.275 & 0.300 & 0.182 \\
Min. & 0.026 & 0.026 & 0.187 & 0.002 & 0.002 & 0.224 \\
Max. & 1.000 & 1.000 & 1.000 & 1.000 & 1.000 & 1.000 \\
\hline
\end{tabular}

Second, we analyse the influence of PDOs on the efficiency of the companies analysed. As can be seen in Table 3, the average efficiency estimated with the CRS model for PDO wineries is 0.457, which is higher than the average efficiency of non PDO wineries (0.39). With the VRS model we find values of 0.495 for PDO wineries and 0.443 for non PDO wineries. Regarding cheese factories, results also show that the average efficiency estimated with the CRS model for PDO cheese factories is 0.436 , which is higher than the average efficiency of non PDO cheese factories (0.346). With the VRS model we find values of 0.491 for PDO cheese factories and 0.394 for non PDO cheese factories. In both cases the non-parametric Mann-Whitney tests show that the PDO companies have significantly higher economic efficiency than the non PDO companies, which supports H1 that PDO labels positively influence the economic efficiency of their member companies. This result reveals the importance of PDO labels in the commercialisation of experience products, insofar as they reduce the risk perceived by consumers when making their purchases. It seems, therefore, that a PDO, as a collective reputation indicator, foments efficient investment in quality by the member companies, which would explain the greater economic efficiency of companies in a PDO label. Because H1 is based on the idea that consumers rely on the quality reputation of a group of companies (Shapiro, 1983), we have obtained a "proxy" variable between PDO and company efficiency in terms of the quality of the wines of the PDO and non-PDO wineries ${ }^{5}$ (where the quality is obtained from "Los Mejores Vinos de España Repsol”, which publishess expert blind tasting quality scores of the best wines of Spain -those that score over 85 points- in a 100 point scale). The results show that the average quality of the PDO wines $\left(\right.$ Mean $_{\mathrm{PDO}}=90.75 ;$ S.D. $\left.=\ldots ; \mathrm{n}=\ldots\right)$ is higher than that of the non-PDO wines $\left(\mathrm{Mean}_{\mathrm{nonPDO}}=90.32\right.$; S.D. $=\ldots ; n=\ldots)$, with this difference being significant $(p=0.00)$. It would support the idea of Fishman et al. (2008) that a company that chooses to join a collective label with a certain level of quality has to

\footnotetext{
${ }^{5}$ Lack of information on cheese quality in Spain impedes the comparative analysis of average quality of PDO companies and the average quality of non-PDO companies.
} 
invest in reputation through the production of quality products as it will obtain high profits from its investment in quality derived from the large number of consumers that are adequately informed about the past quality of the group. With regard to scale efficiency, although the PDO companies (both wineries and cheese factories) have slightly better values than the non PDO companies, the result is not significant.

TABLE 3. COMPARISON BETWEEN THE EFFICIENCY ESTIMATIONS OF PDO AND NON PDO COMPANIES

\begin{tabular}{|c|c|c|c|c|c|c|c|}
\hline & & \multicolumn{3}{|c|}{ PDO label companies } & \multicolumn{3}{|c|}{ Non PDO label companies } \\
\hline & & Ef. CRS & Ef. VRS & Ef. SE & Ef. CRS & Ef. VRS & Ef. SE \\
\hline \multirow[t]{8}{*}{ Wine } & Average & 0.457 & 0.495 & 0.930 & 0.390 & 0.443 & 0.917 \\
\hline & S.D. & 0.286 & 0.298 & 0.146 & 0.213 & 0.251 & 0.157 \\
\hline & Min. & 0.026 & 0.026 & 0.187 & 0.033 & 0.034 & 0.278 \\
\hline & Max. & 1.000 & 1.000 & 1.000 & 1.000 & 1.000 & 1.000 \\
\hline & U-Mann-Whitney & 166985.5 & 166742.0 & 177808.5 & & & \\
\hline & W-Wilcoxon & 262688.5 & 262445.0 & 273511.5 & & & \\
\hline & $\mathrm{Z}$ & -1.988 & -2.031 & -0.224 & & & \\
\hline & Prob $>Z$ & 0.047 & 0.042 & 0.823 & & & \\
\hline \multirow[t]{8}{*}{ Cheese } & Average & 0.436 & 0.491 & 0.898 & 0.346 & 0.394 & 0.893 \\
\hline & S.D. & 0.320 & 0.341 & 0.185 & 0.249 & 0.277 & 0.180 \\
\hline & Min. & 0.005 & 0.018 & 0.230 & 0.002 & 0.002 & 0.224 \\
\hline & Max. & 1.000 & 1.000 & 1.000 & 1.000 & 1.000 & 1.000 \\
\hline & U-Mann-Whitney & 16807.50 & 16999.0 & 15924.0 & & & \\
\hline & W-Wilcoxon & 23023.5 & 23215.0 & 21140.0 & & & \\
\hline & $\mathrm{Z}$ & -2.056 & -2.255 & -1.144 & & & \\
\hline & Prob $>Z$ & 0.040 & 0.024 & 0.253 & & & \\
\hline
\end{tabular}

Further, to test the central hypothesis of the paper we also carry out a regression analysis, which allows us to control the effect of several characteristics of the company on its efficiency. As can be seen in Table 4 the results show that the coefficient of the dummy variable reflecting PDO membership is positive and significant, in both the wine and cheese sectors. This result shows that the PDO companies have significantly higher economic efficiency than the non PDO companies, which supports H1 that PDO labels positively influence the economic efficiency of their member companies. The results also show that in both sectors the coefficient of the age of the company (number of years since established) is positive and significant, which indicates a positive effect on the economic efficiency of the company. This result can be explained by the age of the company being linked with better market knowledge and better individual company reputation. In fact, as a company begins to establish itself within a community, its reputation will be more widespread and it will have positive word of mouth (Thomas et al., 1998). With regard to remuneration levels, the coefficient of the variable reflecting the average wage paid is negative and significant for the wineries, showing a 
negative effect of the average level of wages paid on the efficiency of the company. This could be because any wage increases that are not accompanied by productivity increases will raise labour costs per product unit, which would necessarily lead to price increases or reduced company economic efficiency. However, this coefficient is positive and significant for the cheese factories, showing a positive effect of the average wage level on efficiency. This empirical finding is consistent with Sánchez and Aragón (2002), who state that the relationship between average remuneration level and company efficiency depends on contextual or situational factors. Specifically, this result shows the importance of adequate employee motivation in labour intensive sectors such as the cheese sector. With regard to the influence of company size, the coefficient is positive and significant in both sectors, which suggests that as company size increases economic efficiency will be higher. This could be explained because company size explains individual reputation as bigger companies have more financial resources to invest in quality and promotion (Castriota and Delmastro, 2008). Thus, larger companies are able to attract the attention of the media and gain visibility: "large companies tend to receive a lot of public scrutiny. Availability of information could disproportionately benefit large companies by inflating audiences' familiarity with their activities” (Fombrun and Shanley, 1990; Castriota and Delmastro, 2008).

\section{TABLE 4. ESTIMATION OF THE DETERMINANT FACTORS OF COMPANY EFFICIENCY (TOBIT)}

\begin{tabular}{|c|c|c|c|c|c|}
\hline \multirow{3}{*}{ Wine } & Variable & Coeff. & S.D. & Z-Statistic & Prob. \\
\cline { 2 - 6 } & C & 0.952 & 0.033 & 2.852 & 0.000 \\
& PDO (dummy variable) & 0.084 & 0.012 & 7.305 & 0.000 \\
& Company age & 0.002 & 0.001 & 4.017 & 0.000 \\
& Average Wage paid & -0.036 & 0.008 & -4.518 & 0.000 \\
& Company size & 0.059 & 0.007 & 8.103 & 0.000 \\
\hline Cheese & Log likelihood & -75.710 & & & 0.840 \\
& C & 0.022 & 0.107 & 2.634 & 0.008 \\
& PDO (dummy variable) & 0.079 & 0.030 & 2.430 & 0.015 \\
& Company age & 0.003 & 0.001 & 3.691 & 0.000 \\
& Average Wage paid & 0.145 & 0.039 & 2.257 & 0.024 \\
& Company size & 0.022 & 0.010 & & \\
\hline
\end{tabular}

Finally, in order to examine the effect of the collective reputation indicators (i.e. PDO) on company efficiency, we estimate the average efficiency of PDO wine and cheese companies. To ensure representation of the average efficiency of each PDO, we only use those that have more than 3 companies. Accordingly, we estimate the average efficiency of the wineries in 34 PDOs and of the cheese companies in 12 PDOs. With the VRS model, the average efficiencies of the PDO wineries 
show wide differences (see Table 5), ranging between 0.713 and 0.708 for the two most efficient PDOs (PDO 8 and PDO 2) and 0.251 for the least efficient (PDO 24). The non-parametric KruskalWallis test shows that the difference between the average efficiencies of the different PDO wineries is significant at a level below $1 \%$. This result shows that there is not a homogenous perception of the collective reputation indicators of the wine PDOs in the market, with a differential effect on their economic efficiency. According to Cambra and Villafuerte (2009), this would suggest that consumers not only choose PDO products over non PDO products but are also capable of distinguishing among different PDO wines: for example, it is common to hear restaurant clients ordering wine from a particular PDO.

TABLE 5. ESTIMATIONS OF AVERAGE EFFICIENCY OF THE DIFFERENT PDO WINE LABELS

\begin{tabular}{|c|c|c|c|c|c|c|c|c|c|}
\hline PDO & & RS & RS & SE & PDO & & RS & VRS & SE \\
\hline & $\begin{array}{l}\text { Mean } \\
\text { S.D. }\end{array}$ & $\begin{array}{l}545 \\
341\end{array}$ & $\begin{array}{l}565 \\
337\end{array}$ & $\begin{array}{l}0.947 \\
0.098\end{array}$ & $\begin{array}{c}\text { PDO 19 } \\
(n=24)\end{array}$ & $\begin{array}{l}\text { Mean } \\
\text { S.D. }\end{array}$ & $\begin{array}{l}.432 \\
.280\end{array}$ & $\begin{array}{l}0.465 \\
0.291\end{array}$ & $\begin{array}{l}0.949 \\
0.136\end{array}$ \\
\hline & $\begin{array}{l}\text { Mean } \\
\text { S.D. }\end{array}$ & & $\begin{array}{l}708 \\
344\end{array}$ & $\begin{array}{l}0.998 \\
0.002\end{array}$ & $\begin{array}{c}\text { PDO } 20 \\
(n=37)\end{array}$ & $\begin{array}{l}\text { Mean } \\
\text { S.D. }\end{array}$ & & $\begin{array}{l}.446 \\
.279\end{array}$ & $\begin{array}{l}0.945 \\
0.146\end{array}$ \\
\hline & $\begin{array}{l}\text { Mean } \\
\text { S.D. }\end{array}$ & & $\begin{array}{l}319 \\
245\end{array}$ & $\begin{array}{l}0.948 \\
0.103\end{array}$ & & $\begin{array}{l}\text { Mean } \\
\text { S.D. }\end{array}$ & & $\begin{array}{l}0.422 \\
0.241\end{array}$ & $\begin{array}{l}0.998 \\
0.003\end{array}$ \\
\hline & $\begin{array}{l}\text { Mean } \\
\text { S.D. }\end{array}$ & & $\begin{array}{l}394 \\
148\end{array}$ & $\begin{array}{l}0.884 \\
0.217\end{array}$ & $\begin{array}{c}\text { PDO } 22 \\
(n=10)\end{array}$ & $\begin{array}{l}\text { Mean } \\
\text { S.D. }\end{array}$ & & & $\begin{array}{l}0.996 \\
0.006\end{array}$ \\
\hline $\begin{array}{l}\text { PDO } 5 \\
(n=13)\end{array}$ & $\begin{array}{l}\text { Mean } \\
\text { S.D. }\end{array}$ & & $\begin{array}{l}408 \\
287\end{array}$ & $\begin{array}{l}.979 \\
.048\end{array}$ & & $\begin{array}{l}\text { Mean } \\
\text { S.D. }\end{array}$ & & & $\begin{array}{l}0.903 \\
0.197\end{array}$ \\
\hline $\begin{array}{l}\text { PDO 6 } \\
(n=22)\end{array}$ & $\begin{array}{l}\text { Mean } \\
\text { S.D. }\end{array}$ & & $\begin{array}{l}604 \\
256\end{array}$ & $\begin{array}{l}0.911 \\
0.171\end{array}$ & & $\begin{array}{l}\text { Mean } \\
\text { S.D. }\end{array}$ & & $\begin{array}{l}0.251 \\
0.124\end{array}$ & $\begin{array}{l}0.997 \\
0.003\end{array}$ \\
\hline & $\begin{array}{l}\text { Mean } \\
\text { S.D. }\end{array}$ & & $\begin{array}{l}.671 \\
.325\end{array}$ & $\begin{array}{l}0.965 \\
0.095\end{array}$ & & $\begin{array}{l}\text { Mean } \\
\text { S.D. }\end{array}$ & & & $\begin{array}{l}0.909 \\
0.141\end{array}$ \\
\hline & $\begin{array}{l}\text { Mean } \\
\text { S.D. }\end{array}$ & & & & & $\begin{array}{l}\text { Mean } \\
\text { S.D. }\end{array}$ & & & $\begin{array}{l}0.897 \\
0.197\end{array}$ \\
\hline $\begin{array}{c}\text { PDO } 9 \\
(n=6)\end{array}$ & $\begin{array}{l}\text { Mean } \\
\text { S.D. }\end{array}$ & & & & & $\begin{array}{l}\text { Mean } \\
\text { S.D. }\end{array}$ & & & $\begin{array}{l}0.963 \\
0.068\end{array}$ \\
\hline $\begin{array}{c}\text { PDO } 10 \\
(n=4)\end{array}$ & $\begin{array}{l}\text { Mean } \\
\text { S.D. }\end{array}$ & & & & & $\begin{array}{l}\text { Mean } \\
\text { S.D. }\end{array}$ & & & $\begin{array}{l}0.996 \\
0.004\end{array}$ \\
\hline $\begin{array}{c}\text { PDO 11 } \\
(n=18)\end{array}$ & $\begin{array}{l}\text { Mean } \\
\text { S.D. }\end{array}$ & & & & $\begin{array}{c}\text { PDO } 29 \\
(n=6)\end{array}$ & $\begin{array}{l}\text { Mean } \\
\text { S.D. }\end{array}$ & & & $\begin{array}{l}0.943 \\
0.132\end{array}$ \\
\hline & $\begin{array}{l}\text { Mean } \\
\text { S.D. }\end{array}$ & & & & & $\begin{array}{l}\text { Mean } \\
\text { S.D. }\end{array}$ & & & \\
\hline & & & & & & $\begin{array}{l}\text { Mean } \\
\text { S.D. }\end{array}$ & & & $\begin{array}{l}0.947 \\
0.137\end{array}$ \\
\hline $\begin{array}{c}\text { PDO } 14 \\
(n=4)\end{array}$ & $\begin{array}{l}\text { Mean } \\
\text { S.D. }\end{array}$ & & & & $\begin{array}{c}\text { PDO } 32 \\
(n=5)\end{array}$ & $\begin{array}{l}\text { Mean } \\
\text { S.D. }\end{array}$ & & & $\begin{array}{l}0.881 \\
0.260\end{array}$ \\
\hline $\begin{array}{c}\text { PDO } 15 \\
(n=6)\end{array}$ & $\begin{array}{l}\text { Mean } \\
\text { S.D. }\end{array}$ & & & & & $\begin{array}{l}\text { Mean } \\
\text { S.D. }\end{array}$ & & & $\begin{array}{l}0.960 \\
0.091\end{array}$ \\
\hline $\begin{array}{c}\text { PDO } 16 \\
(n=4)\end{array}$ & $\begin{array}{l}\text { Mean } \\
\text { S.D. }\end{array}$ & $\begin{array}{l}0.287 \\
0.158\end{array}$ & $\begin{array}{l}0.329 \\
0.204\end{array}$ & $\begin{array}{l}0.916 \\
0.105\end{array}$ & $\begin{array}{r}\mathrm{PDO} \\
(\mathrm{n}=2\end{array}$ & $\begin{array}{l}\text { Mean } \\
\text { S.D. }\end{array}$ & & $\begin{array}{l}0.551 \\
0.306\end{array}$ & $\begin{array}{l}0.934 \\
0.160\end{array}$ \\
\hline PDO 17 & Mean & 0.444 & 0.449 & 0.985 & $\begin{array}{l}\text { Various } \\
\text { PDO } \\
(n=110)\end{array}$ & Mean & 0.428 & 0.488 & 0.903 \\
\hline $\begin{array}{c}\text { PDO } 18 \\
(n=7)\end{array}$ & $\begin{array}{l}\text { Mean } \\
\text { S.D. }\end{array}$ & $\begin{array}{l}0.476 \\
0.252\end{array}$ & $\begin{array}{l}0.484 \\
0.247\end{array}$ & $\begin{array}{l}0.976 \\
0.053\end{array}$ & $\begin{array}{l}\text { No PDO } \\
(n=437)\end{array}$ & $\begin{array}{l}\text { Mean } \\
\text { S.D. }\end{array}$ & $\begin{array}{l}0.390 \\
0.213\end{array}$ & $\begin{array}{l}0.443 \\
0.251\end{array}$ & $\begin{array}{l}0.917 \\
0.157\end{array}$ \\
\hline
\end{tabular}


Regarding the cheese sector, the average VRS efficiencies of the PDO cheese companies show some differences (see Table 6), ranging between 0.572 and 0.564 for the two most efficient PDOs (PDO 9 and PDO 12) and 0.144 for the least efficient (PDO 1). However, in this case, the Kruskal-Wallis test shows that the difference between the average efficiencies of the different PDO cheese companies is not significant, showing a structural difference with the wine market.

The structural difference between these two markets could be explained in the following way: PDOs were introduced in Spain, as in France and Italy, to protect wines that, due to their place of origin, had specific characteristics that made them distinctive. In 1932 the first Spanish "Statue of wine and alcohol" was approved, which laid the groundwork for the PDOs, and in 1970 a new statute was approved that allowed PDOs to include all foodstuffs (Díaz, 2011). At present there are 80 wine PDOs in Spain, some very old such as Rioja, which has attained the level of "authorized", for which it has to satisfy certain rules and age requirements; others which now have a reduced commercial importance, such as Jerez, whose excellent quality and almost unique product is losing its market share; others that entered the market some years ago and are now established, such as Ribera del Duero; some, such as Cava, which has been so internationalized that it is the biggest sparkling wine in the world; other more recent entrants that have surprised consumers with their quality, such as Toro or Somontano; others that are opening new market with promising futures, such as Madrid, which for years has been the only one bearing the name of a capital city; and many more that are in a growth phase.

It terms of cheese, around the middle of the $20^{\text {th }}$ century there was growing interest in certifying certain cheeses whose traditional manufacturing methods, based on local raw materials, gave them prestige and individual personality and, therefore, differentiated characteristics (Frutos and Ruiz, 2012). However, the "Cheese catalogue” was not published until 1969 and led to the approval of the first cheese PDOs (Díaz, 2011). Actually only 8\% of Spanish cheese production in 2010 is covered by PDOs (Frutos and Ruiz, 2012), and there are only 27 PDOs. The Spanish cheese industry was a late developer because of the lack of availability of milk, and this factor favoured the preservation of traditional cheeses, made in small regions with artisan methods. Nowadays, although cheese makers emphasize quality and tradition without renouncing modernization and a commercial focus, they still give great importance to local development and to keeping an industry linked to its roots at a local or 
regional scale (Frutos and Ruiz, 2012). Finally, production levels of Spanish PDO cheese differ vastly to those of Italy and France. These two countries have reached far higher production levels because of their many differential factors, especially the willingness of the commercial sector (large supermarkets) to stock and promote a wide range of their PDO cheeses (Sanz, 1995).

TABLE 6. ESTIMATIONS OF AVERAGE EFFICIENCY OF THE DIFFERENT PDO CHEESE LABELS

\begin{tabular}{|c|c|c|c|c|c|c|c|c|c|}
\hline PDO & & CRS & VRS & SE & PDO & & CRS & VRS & SE \\
\hline PDO 1 & Mean & 0.092 & 0.144 & 0.690 & PDO 7 & Mean & 0.343 & 0.344 & 0.993 \\
(n=3) & S.D. & 0.003 & 0.045 & 0.258 & $(n=6)$ & S.D. & 0.343 & 0.343 & 0.007 \\
\hline PDO 2 & Mean & 0.435 & 0.504 & 0.804 & PDO 8 & Mean & 0.287 & 0.300 & 0.964 \\
(n=4) & S.D. & 0.420 & 0.409 & 0.324 & (n=3) & S.D. & 0.104 & 0.114 & 0.028 \\
\hline PDO 3 & Mean & 0.345 & 0.423 & 0.898 & PDO 9 & Mean & 0.502 & 0.572 & 0.905 \\
(n=3) & S.D. & 0.175 & 0.306 & 0.175 & (n=47) & S.D. & 0.355 & 0.367 & 0.199 \\
\hline PDO 4 & Mean & 0.310 & 0.320 & 0.978 & PDO 10 & Mean & 0.500 & 0.533 & 0.951 \\
(n=4) & S.D. & 0.243 & 0.254 & 0.018 & (n=15) & S.D. & 0.301 & 0.317 & 0.079 \\
\hline PDO 5 & Mean & 0.402 & 0.432 & 0.936 & PDO 11 & Mean & 0.478 & 0.479 & 0.994 \\
(n=3) & S.D. & 0.040 & 0.063 & 0.068 & (n=3) & S.D. & 0.459 & 0.457 & 0.005 \\
\hline PDO 6 & Mean & 0.424 & 0.539 & 0.864 & PDO 12 & Mean & 0.412 & 0.564 & 0.687 \\
(n=3) & S.D. & 0.198 & 0.367 & 0.186 & (n=3) & S.D. & 0.326 & 0.381 & 0.338 \\
\hline \multicolumn{7}{|c|}{ Note. We only present average values of PDOs with more than 3 companies. }
\end{tabular}

The wide difference among average efficiencies of the PDO wine companies provokes the question of what distinguishes highly efficient companies from those showing lower efficiency. Thus, we have estimated a regression model for the PDO wineries where the dependent variable is the company economic efficiency and as independent variables we consider some specific variables related to the company (age, wages and size) and some specific variables related to the PDO in which the company operates: size of the PDO (number of wineries in the PDO), international market of the PDO (percentage of hectoliters of the PDO sold abroad) and age of the PDO (number of years since the PDO was established). Table 7 shows the results.

As expected, the coefficients of the company characteristics variables (age, wages and size) have the same significant signs as in Table 4. Regarding the variables related to the PDO in which the winery operates, the positive and significant coefficient of the number of producers of the PDO shows that as the number of producers in the PDO increases company efficiency is higher. This result is explained because large coalitions have higher resources for marketing campaigns and a larger buyer base which, combined with the word-of-mouth phenomena, make big coalitions more visible to the market (Rob and Fishman, 2005; Castriota and Delmastro, 2009). The positive and significant coefficient of the variable international market of the PDO shows that as the percentage of the international market of the PDO increases company efficiency is also higher, which could be explained by consolidated 
prestige in the international markets. Thus, the internationalization of some PDOs such as Cava, which has allowed it to overtake the volume of the mythical and much admired champagne; and Spanish wines are more and more well known, receiving maximum scores from Robert Parker and are also taking positions in emerging markets, especially the Asian markets (Díaz, 2011). Finally, the coefficient of the age of the PDO is not significant. Although we expected a positive and significant effect because older PDOs have built their reputations over time and it takes time for the age of the coalition and of its brand to be known among consumers (Castriota and Delmastro, 2009), the lack of significance would reflect that the new wine "boom" is a relatively recent phenomenon (Roberts and Reagans, 2007), and the markets may favour PDOs founded during the last two decades. For example, some PDOs have been relatively recently created but are surprising observers with their quality, such as Toro or Somontano (Díaz, 2011).

\section{TABLE 7. DETERMINANT FACTORS OF PDO WINERIES EFFICIENCY}

\begin{tabular}{|c|c|c|c|c|}
\hline Variable & Coeff. & S.D. & Z-Statistic & Prob. \\
\hline C & 1.079 & 0.057 & 1.887 & 0.000 \\
Company characteristics & & & & \\
Company age & 0.003 & 0.001 & 3.582 & 0.000 \\
Average Wage paid & -0.071 & 0.011 & -6.307 & 0.000 \\
Company size & 0.059 & 0.011 & 5.563 & 0.000 \\
PDO characteristics & & & & \\
Wineries in the PDO & 0.016 & 0.008 & 1.911 & 0.056 \\
International market of the PDO & 0.001 & 0.000 & 2.975 & 0.003 \\
PDO age & 0.000 & 0.000 & -0.293 & 0.770 \\
Log likelihood & 34.861 & & & \\
\hline
\end{tabular}

\section{Conclusions.}

The objective of this study is to estimate the efficiency of PDO companies in two experience goods industries, and to explain it through both PDO labels, as collective reputation indicators, as well as different characteristics of the member companies. The basic assumption is that a PDO label has a positive impact on the economic efficiency of its member companies because a PDO label is a collective reputation indicator that foments efficient investment in quality in terms of members' returns.

The results of the study, applied to a sample of 1,257 Spanish wineries and a sample of 378 Spanish cheese factories show low average levels of efficiency. Additionally, the average economic efficiency 
of PDO companies is significantly higher than that of non PDO companies, which allow us to generalise the influence of PDO labels on company efficiency to both experience good industries. Finally, some characteristics of the company influence company efficiency. The age and size of the company increase efficiency in both industries while wage levels have a negative effect on wineries' efficiency but a positive effect on cheese factories’ efficiency.

The following managerial implications are relevant: The finding of efficiency differences between PDO and non PDO companies supports the protection policy of PDO developed by Spanish Autonomous Communities, given that PDOs have the capacity to affect the efficiency of their member companies. If we extend the theoretical model of collective reputation (Tirole, 1996), which focuses on price equilibrium, the result obtained in this study of the differential effect of the collective label on company efficiency suggests that wine and cheese consumers formulate their quality predictions on the output of an individual company using information on the output of other similar companies, giving a primordial value to the quality indicators of the group. The value that consumers assign to Protected Designations of Origin implies that their Regulatory Councils should provide constant information to the market on the characteristics of their products.

The results obtained also suggest that choosing a collective label strategy can play an important role in the success of a company; in particular, a PDO label can help a company be more efficient because it can promote more efficient investment in quality by its members in terms of the returns on this investment. In fact, the products with this collective reputation can be sold with a price premium, which is necessary for producers to invest in quality and reputation (Quagrainie et al., 2003). Moreover, although a top company with an outstanding individual reputation may have enough resources to sustain high investment in quality on its own, it will also be motivated to participate in collective branding because the high production levels associated with a collective brand can also have a positive impact on individual efficiency due to the increased number of units whose quality is observed by consumers increasing the collective reputation effect. However, PDO labels should not be seen as a guarantee against failure. In fact, PDO labels contribute favourably to company efficiency but they only explain a percentage of efficiency variability. Certain characteristics of the company also 
help explain company efficiency, such as the age, size and wage levels of the company. The result that the age of the company increases its efficiency suggests that company age entails better market knowledge and better individual company reputation. The result that the size of the company increases its efficiency suggests that bigger companies have more financial resources to invest in quality and promotion; therefore, larger companies would be able to attract the attention of the media and gain visibility. Finally, the result that wage levels have an influence on efficiency suggests the importance of employee wage levels in labour intensive industries.

Although the intention of this study is to contribute to the understanding of the impact of PDO label strategies on company efficiency, it has some limitations. Lack of information impedes the analysis of other factors that could explain company efficiency in a PDO label, such as the strength of the PDO label. As further lines of research we suggest analysing the influence of the strength of the different PDO labels on the efficiency of the companies belonging to them. Basically, a collective label can promote more efficient investment in quality in its member companies because the collective label covers a larger market segment than any of its member companies, and given that the information on past quality is imperfectly disseminated, for example by word of mouth, the consumers of any given member company have a greater probability of having previously interacted with past consumers of the collective label than with those of a company outside the collective. But, it would also be necessary to consider the strength of the PDO label because brand strength is one of the most central components of any model of brand equity, and not only can brand strength be conceptualized in terms of consumers' attitude toward the brand with respect to quality, but it also integrates behavioural dimensions such as brand loyalty and brand share across the markets in which the brand competes (Smith and Park, 1992; Aaker, 1991); so it is expected that strength of the PDO label influences company efficiency, because a stronger PDO label should be better able to stimulate trial of the products of its members than a PDO label of lower strength. Second, the analysis is a cross sectional study, which prevents us from finding the longitudinal nature of the effect. Because collective reputation is a long-term, path dependent process, stereotypes about the expected quality of a PDO are history dependent (Tirole, 1996), so it would be necessary to develop a dynamic model to explain persistence in collective reputations and thus its expected positive effect on company efficiency. 
Finally, and ideally, a research question in the future would be the design of an experiment that considers other experience goods (e.g., ham) and other parts of the European Union, in order to generalize the results obtained in our paper. We would expect to see similar results to those of our paper, because consumers would use collective reputation when the quality of a product is imperfectly observable prior to purchase (experience good).

\section{References}

Aaker, D.A. (1991) Managing brand equity: Capitalizing on the value of a brand name, New York: The Free Press.

Akerlof, G.A. (1970) The market for lemons: quality uncertainty and the market mechanism. Q. J. Econ., 84(3): 488-500.

Allen, F. (1984) Reputation and product quality. Rand Journal of Economics, 15, 311-327.

Banker, R.D., Charnes, A. and Cooper, W.W. (1984) Some models for estimating technical and scale inefficiencies in Data Envelopment Analysis. Manag. Sci., 30(9): 1078-1092.

Bouamra-Mechemache, Z. and Chaaban, J. (2010) Protected Designation of Origin revisited. J. Agric. Food Ind. Organiz., 8, 1-27.

Bravo-Ureta, B., Solís, D., Moreira-López, V.H., Maripini, J.F., Thiam, A. and Rivas, T. (2007) Technical efficiency in farming: A meta-regression analysis. J. Prod. Anal., 27, 57-72.

Bucklin, L.P. (1978): Productivity in Marketing. Chicago: A.M.A.

Cambra, J. and Villafuerte, A. (2009) Denominaciones de origen e indicaciones geográficas. Justificación de su empleo y valoración de su situación actual en España, Mediterráneo Económico, 15, 329-350.

Castriota, S. and Delmastro, M. (2008) Individual and collective reputation: Lessons from the wine market. working paper 30, American Association of Wine Economists. 
Castriota, S. and Delmastro, M. (2009) The economics of collective reputation: Minimum quality standards, vertical differentiation and optimal group size. Working paper, 50, American Association of Wine Economists.

Charnes, A., Cooper, W.W. and Rhodes, E. (1978) Measuring the efficiency of decision making units. Eur. J. Oper. Res., 2, 429-444.

Charnes, A., Cooper, W.W. and Rhodes, E. (1981) Evaluating program and managerial efficiency: An application of Data Envelopment Analysis to program follow through. Manag. Sci., 27(6): 668697.

Díaz, I. (2011) Denominaciones de origen e indicaciones geográficas como garantía de calidad, Distribución y Consumo, mayo-junio, 5-21.

Donthu, N. and Yoo, B. (1998) Retail productivity assessment using data envelopment analysis. J. Retail., 74(1): 89-105.

Doutt, J.T. (1984) Comparative productivity performance in fast-food retail distribution. J. Retail., 60, 98-106.

Erdem, T. and Swait, J. (1998) Brand equity as a signalling phenomenon. J. Consum. Psych., 7(2): 131-157.

Erdem, T., Swait, J., Broniarczyk, S. Chakravarti, D., Kapferer, J.N. Keane, M., Roberts, J., Steenkamp, J.B. and Zettelmeyer, F. (1999) Brand equity, consumer learning and choice. Mark. Lett., 10(3): 301-318.

Fernández-Barcala, M. and González-Díaz, M. (2006) Brand equity in the European fruit and vegetable sector: A transaction cost approach. Int. J. Res. Mark., 23, 31-44.

Fishman, A., Finkelshtain, I., Simhon, A. and Yacouel, N. (2008) The economics of collective brands. Discussion Paper 14.08, The Hebrew University of Jerusalem.

Fombrun, C. and Shanley, M. (1990) What's in a name? Reputation building and corporate strategy, The Academy of Management Journal, 33(2), 233-258. 
Frutos, L. and Ruiz, E. (2012) Los quesos con indicación geográfica: Su importancia en el Sistema agroalimentario local, in Frutos, L. and Ruiz, E. (eds.), Los productos con indicación geográfica en el sistema agroalimentario español. Tradición y modernidad, IFC, Zaragoza, 73-98.

Hoff, A. (2007) Second stage DEA: Comparison of approaches for modelling the DEA score. Eur. J. Oper. Res., 181, 425-435.

Gómez-Mejía, L.R. and Balkin, D.B. (1992): Compensation, organizational strategy, and firm performance, South-Western Publishhing, Cincinnati, OH.

Ingene, C.A. (1982) Labor productivity in retailing. J. Mark., 46(4): 75-90.

Jensen, M.C. and Meckling, W.C. (1976) Theory of the Firm: Managerial Bahavior, Agency Costs and Ownership Structure. J. Financ. Econ., 3, 305-360.

Jin, G.Z. and Leslie, P. (2009) Reputational incentives for restaurant hygiene. Amer. Econ. J.: Microecon., 1(1): 237-267.

Klein, B. and Leffler, K.B. (1981) The role of market forces in assuring contractual performance. JPolit. Econ., 89(4): 615-641.

Kreps, D.M., Milgrom, P.R., Roberts, J. and Wilson, R.J. (1982) Rational cooperation in the finitely repeated prisoner’s dilemma. J. Econ. Theory, 27(2): 245-252.

Kreps, D.M. and Wilson, R. (1982) Reputation and imperfect information. J. Econ. Theory, 27, 253279.

Landon, S. and Smith, C.E. (1997) The use of quality and reputation indicators by consumers: The case of Bordeaux wine. J. Consum. Policy, 20(3): 289-323.

Landon, S. and Smith, C.E. (1998) Quality expectations, reputation, and price. South. Econ. J., 64(3): 628-647.

Loureiro, M.L. and McCluskey, J.J. (2000) Assessing consumer response to protected geographical identification labelling. Agribusiness, 16(3): 309-320. 
Lusch, R.F. and Serpkenci, R.R. (1990) Personal differences, job tension, job outcomes and store performance: a study of retail store managers. J. Mark., 54(1): 85-101.

MMAMRM (2009): Datos de los vinos de calidad producidos en regiones determinadas (V.C.P.R.D.) Campaña 2008/2009, Secretaría General de Medio Rural. Ministerio de Medio Ambiente y Medio Rural y Marino, Madrid.

Nayyar, P.R., (1990) Information asymmetries: a source of competitive advantage for diversified service firms. Strat. Manag. J., 11, 513-519.

Pilling, B.K., Henson, S.W. and Yoo, B. (1995) Competition among franchises, company-owned units and independent operations: A population ecology application. J. Mark. Channels, 4(1): 177-195.

Quagrainie, K.K., McCluskey, J.J. and Loureiro, M.L. (2003) A latent structure approach to measuring reputation. Southern Economic Journal, 69(4): 966-977.

Ratchford, B.T. and Stoops, G.T. (1988) A model and measurement approach for studying retail productivity. J. Retail., 64, 241-263.

Rob, R. and Fishman, A. (2005) Is bigger better? Customer base expansion through word-of-mouth reputation, Journal of Political Economy, 113(5): 1146-1162.

Roberts, P. and Reagans, R. (2007) Critical exposure and price-quality relationships for new world wines in the U.S. market, Journal of Wine Economics, 2(1), 56-69.

Rogerson, W.P. (1987) The dissipation of profits by brand name investment and entry when price guarantees quality. J. Polit. Econ., 95, 797-809.

Rosen, W.P. (1974) Hedonic prices and implicit markets: Product differentiation in pure competition. J. Politi. Econ, 82, 34-55.

Sánchez, G. and Aragón, A. (2002) Retribución del directivo, factores contextuales y resultados de la empresa: evidencia empírica en el sector químico-farmacéutico. Cuad. Econ. Direcc. Emp., 12, 315-336.

Sánchez, G. and Aragón, A. (2003) Top managers'compensation, strategic orientations, and firm performance: empirical evidence from Spanish firms. Manag. Res., 1(1): 27-44. 
Sanz, M. (1995) Los quesos con denominación de origen frente a la moderna distribución comercial, Distribución y Consumo, agosto/septiembre, 120-123.

Schamel, G. (2000) Individual and collective reputation indicators of wine quality. Discussion paper 9, University of Adelaide.

Shapiro, S. (1983) Premium for high quality products as returns to reputation. Quart. J. Econ., 98, 660679.

Schulze, W.S., Lubatkin, M.H., Dino, R.N. and Buchholtz, A.K. (2001) Agency Relationships in Family Firms: Theory and Evidence. Organ. Sci., 12(2): 99-116.

Thomas, R.R., Barr, R.S., Cron, W.L. and Slocum, J.W. Jr. (1998) A process for evaluating retail store efficiency: A restricted DEA approach. Int. J. Res. Mark., 15(5): 487-503.

Smith, D. and Park, C. (1992) The effects of brand extensions on market share and advertising efficiency, Journal of Marketing Research, 29(3), 296-313.

Tirole, J. (1988): The Theory of Industrial Organization, Massachusetts Institute of Technology, Boston.

Tirole, J. (1996) A Theory of collective reputation (with application to corruption and firm quality) Rev. Econ. Stud., 63, 1-22.

Tosi, H.L. and Gómez-Mejía, L.R. (1994) Compensation monitoring and firm performance. Acad. Manag. J., 37, 1002-1016.

Viviani, J.L. (2008) Capital structure determinants: an empirical study of French companies in the wine industry. Int. J. Wine Bus. Res., 20(2): 171-194.

Winfree, J.A. and McCluskey, J. (2008) Collective reputation and quality. Amer. J. Agric. Econ., 87(1): 206-213.

Yoo, B., Donthu, N. and Pilling, B.K. (1997) Channel efficiency: Franchise versus non-franchise systems. J. Mark. Channels, 6(3/4): 1-15. 
Zhu, J. (2000) Multi-factor performance measure model with an application to Fortune 500 companies. Eur. J. Oper. Res., 123, 105-124. 